\title{
Türkiye'de Silah İthalatının İktisadi Büyüme Üzerine Etkisi
}

\author{
The Impact of Arms Imports \\ on Economic Growth in Turkey
}

Cilt: 16

Say1: 35

\author{
Şerif CANBAY* - Derya MERCAN**
}

$\ddot{\partial} z$

Savunma harcamalarinin ülke ekonomilerine katkisinin olup olmadı̆̆, varsa bu etkinin yönünün nasıl olduğu hususunda yapılmış bir çok çalışma mevcuttur. Savunma harcamaları içinde en büyük harcama kalemlerinden olan silah ithalatının gelişmekte olan ülkelerin makroekonomik performanslarina olan etkileri uzun süredir tartsşlan bir konudur. Bu çalışmanın amacı da gelişmekte olan ülkelerden olan Türkiye'nin ödemeler dengesinde büyük açılklara yol açan silah ithalatının iktisadi büyüme üzerindeki etkilerini saptamaya yöneliktir. Bu amaç doğrultusunda çalışmada Türkiye'ye ye ait 1990-2017 dönemi verilerinden hareketle silah ithalatının iktisadi büyüme üzerindeki etkilerini tespit etmek maksadiyla yapısal kirlmalı Gecikmesi Dağttılmış Otoregresif Modele (ARDL) dayalı Sinır Testi yapılmıştır. Çalışmanın test sonuçlarında, kısa dönemde Türkiye'de silah ithalat ile iktisadi büyüme arasinda istatistiki olarak anlamlı bir ilişki bulunamamıs fakat uzun dönemde silah ithalatının iktisadi büyümeyi negatif yönde etkilediği tespit edilmistir.

Anahtar Kelimeler: Silah Ithalat, Savunma Harcamaları, Savunma Sanayii, İktisadi Büyüme, ARDL Sinır Testi.

\footnotetext{
* Dr. Öğr. Üyesi, Düzce Üniversitesi, Akçakoca Bey Siyasal Bilgiler Fakültesi, İktisat Bölümü, ORCID: 0000-0001-6141-7510, e-posta: serifcanbay@duzce.edu.tr, canbay.serif@gmail.com. ** Dr, ORCID: 0000-0003-3011-4423 e-posta: dmercan@ gmail.com.

Geliş Tarihi / Submitted: 18.06.2019

Kabul Tarihi / Accepted: 04.06.2020
} 
708

Güvenlik Stratejileri

Cilt: 16

Sayı: 35

\section{Abstract}

The effects of arms imports, which is the major defense spending item, on the macroeconomic performances of developing countries is a long-debated issue. Therefore, this study aims to determine the impact of arms imports on economic growth, which lead to large deficits in the balance of payments of Turkey. Among the defense spending items, the arms imports have the greatest impact potential on the economies of countries. For this purpose, Bounds Testing based on the structural break Autoregressive Distributed Lag Model (ARDL) was performed to determine the impact of the arms import on economic growth, using the 1990-2017 period data of Turkey. According to the test results of the study, no statistically significant correlation was found between the arms imports in Turkey and economic growth in the short run, but it was found that the arms imports have a negative impact on the economic growth in the long run.

Keywords: Arms Imports, Defense Spending, Defense Industry, Economic Growth, ARDL Bound Test.

\section{Giriş}

İkinci Dünya Savaşı'nın sonlanması ve Amerika Birleşik Devletleri (ABD) ile Sovyet Sosyalist Cumhuriyeti Birliği (SSCB)'nin başrol oyuncuları olduğu Soğuk Savaş dönemi ile birlikte savunma sanayine yönelik yatırımlarda dünya genelinde ciddi bir artış eğilimi söz konusu olmuştur. Savunma sanayisine yönelik bu ilgi yeni silah ve silah teknolojileri ile bunları alıcılarla buluşturacak yeni uluslararası bir pazar ağının da oluşumuna yol açmıştır. Bu yaşanılan süreç dünya genelinde savunma harcamalarını hızlandırıcı bir etki meydana getirmiştir.

SSCB lideri Gorbaçov'un reformlarıyla başlayıp önce Doğu Avrupa'da etkisini gösteren arkasından Almanya'nın birleşmesine varan yolu açan gelişmeler sonrasında ise SSCB'nin dağılması ile sona eren Soğuk Savaş döneminde 1987 yılında zirveye ulaştığı savunma harcamaları daha sonraki yıllarda dünya genelinde azalmaya başlamıştır. Lakin savunma harcamaları dünya genelinde yine 1998 y1lı ile birlikte artmaya başlamış ve özellikle ABD'nin 11 Eylül saldırılarının ardından Afganistan ve Irak'ta yürüttüğü sıcak çatışma bu artış trendini günümüze 
kadar sürdürmüştür. Türkiye'de ise savunma harcamaları da yıllar itibarıla incelendiğinde bütçe içerisindeki payı hep önemli bir yer tutmuştur. Soğuk Savaş bitmiş olmasına rağmen, tarih boyunca hep karışıklıklara sahne olan Balkanlar, Orta Doğu ve Kafkasya üçgeninin ortasında yer alan Türkiye, bu stratejik konumu nedeniyle askerî harcamalarını kısamamıştır.

Dünya güç dengesi içerisinde söz sahibi ülkeler dış politikaları gereği bazı müttefik ülkelere özellikle savunma amaçlı yardımlarda bulunurlar. Gelişmekte olan ülkelerin büyük bir kısmında savunma harcamalarının yüksek oluşu, buna karşılık iç kaynakların yetersizliği dış kaynak ihtiyacını ortaya çıkarmaktadır. Bu çerçevede, "güvenlik yardımı" adı altında yapılan askerî ve ekonomik amaçlı yardımlar çok büyük bir önem taşımaktadır. Fakat bu tür ilişkiler genellikle yardım alan ülkeleri yardım eden ülkelere birçok alanda bağımlı kılmaktadır. Dolayısıyla yerli savunma sanayii ulusal güvenliğin muhafazası için ülkelerin bağımsız politikalar uygulayabilme olanağı sağlamaktadır. Bununla birlikte savunma sanayii ürünleri ithalatçısı ülkelerin bazı durumlarda ürüne sahip olabilmesi için para yeterli olmayabilir. Özellikle ülkelerin menfaatlerinin çatıştığı dönemlerde bazı silah ihracatçısı ülkeler parası peşin ödeyerek alınmak istense dahi silah tedarikine müsaade etmeyebilmektedir. Aynı zamanda devletleri savunma sanayii alt yapılarını oluşturmaya iten nedenlerden bir diğeri ise maruz bırakıldıkları silah ambargolarıdır. Türkiye bu silah ambargolarını 1974 yılında gerçekleşen Kıbrıs Barış Harekâtı sonrasında ve 1990'lı yıllarda da en önemli silah kaynağı olan ABD ile silah ticareti ve savunma iş birliği alanında sorunlar yaşamıştır. Kıbrıs Barış Harekâtı'nın akabinde uygulanan silah ambargosunun ardından 1990'lı y1llarda taahhüt edilen silah sistemleri, ABD yönetimince, Ermeni ve Rum lobilerinin faaliyetleri sonuncunda, terörle mücadelede insan hakları ihlali gibi çeşitli gerekçelerle teslim edilmemiştir. ${ }^{1}$ Türkiye İkinci Dünya Savaşı'ndan

\footnotetext{
${ }^{1}$ Oktay Alnıak, “Türk Savunma Sanayi Hakkında Genel Değerlendirme”, Savunma Sanayiindeki Teknolojik Gelişmeler Sempozyumu, 5-6 Haziran, Kara Harp Okulu, Ankara, 1997, s. 57-58.
}

\section{9}

Güvenlik Stratejileri

Cilt: 16

Say1: 35 
710

Güvenlik Stratejileri

Cilt: 16

Say1: 35

sonra, savunmasını geniş ölçüde askerî yardımlara ve dış kaynaklı silahlara bağlamış ve 1974 yıllarındaki Kıbrıs olayları sonucunda ulusal savunmanın, askerî yardımlar gibi dış tedarik kaynaklarına bağımlılığının oluşturduğu stratejik sakıncaları acı tecrübelerle öğrenmiştir. ${ }^{2}$ Yaşanılan bu olaylar silah ve askerî teçhizatların ithal yolla özellikle de tek kaynaktan sağlanmasının büyük bir risk oluşturduğunu ortaya koymaktadır.

Türkiye 1950'lere kadar savunma sanayinde başarılı olmuş bazı girişimleri 1950'li yıllardan sonra birtakım sebeplerden dolayı sürdürememiştir. 1950'den 1974'e kadar olan süreçte Türkiye silah ve silah sistemleri ihtiyaçlarını ABD, Almanya ve İngiltere başta olmak üzere gelişmiş ülkelerden kısmen hibe ile kısmen eski teknolojilere sahip kullanılmış silahları alarak karşılamıştır. Türkiye bu sürece kadar edinmiş olduğu savunma sanayii kabiliyetlerini de yitirme noktasına gelerek silah ve silah sistemleri üretimlerinde tam anlamıyla dışa bağımlı kalmıştır. Türkiye'ye Kıbrıs meselesi sebebiyle 1974 yılında uygulanan ambargo akılları başa getirmiş ve savunma sanayii alanında alt yapı kurma çalışmalarına başlatma kararı almalarına sebep olmuştur. Türkiye bu gelişmelerden sonra tek yönlü bağımlılığı, çok yönlü bir yapıya dönüştürme ve mümkün olduğunca azaltma gereğini iyice anlamıştır. Dolayısıyla Türkiye'nin savunma sanayii alt yapısını oluşturabilmek için yapacağı çalışmalar ve harcamalar kaçınılmaz olmuştur.

$\mathrm{Bu}$ çalışmanın amacı savunma harcamalarını bir bütün olarak değil sadece silah ithalatı kalemi üzerinden iktisadi büyüme üzerindeki etkisini tespit etmektir. Çalışma savunma harcamalarının iktisadi büyüme ilişkilerini saptamaya çalışan birçok çalışmadan farklı olarak savunma harcamaları yerine silah ithalatının iktisadi büyüme üzerindeki etkilerine ulaşmaya yöneliktir. Çalışmada kurulan model bu yönüyle diğer çalışmalardan farklılık arz etmektedir. Modelin kurgulandığ dönem ise bilhassa Türk Silahlı Kuvvetleri'nin silah, silah sistemleri ve askerî teçhizatlarını millî imkânlar ile üretilebilmesini sağlamak amacı

${ }^{2}$ Muammer Şimşek, Üçüncü Dünya Ülkelerinde ve Türkiye'de Savunma Sanayii, SAGEB Yayınları, Ankara, 1989. s. 1-2. 
ile 1989 yılında Millî Savunma Bakanlığı'na bağlı olarak kurulmuş olan Savunma Sanayii Müsteşarlığı'nın faaliyete geçirildiği dönemden günümüze uzanan dönemi içermektedir. Bu amaç doğrultusunda bu çalışmada öncelikle teorik çerçeve ve literatür incelemesi başlığı altında silah ithalatı ve savunma harcamalarının iktisadi büyüme üzerine etkilerini inceleyen çalışmalara yer verilecektir. Sonrasında ise Türkiye'nin 1990-2017 dönemi silah ithalatı ve iktisadi büyüme verilerinden hareketle zaman serisi analizi yapılacak olup, sonuçlar üzerinden iktisadi ve politik çıkarımlar yapılacaktır.

\section{Teorik Çerçeve ve Literatür İncelemesi}

Savunma harcamalarının iktisadi büyüme üzerindeki etkileri hakkında iki farklı yaklaşım mevcuttur. Bu yaklaşımlardan ilki savunma harcamalarının iktisadi büyümeyi pozitif dışsallıkların da etkisiyle pozitif yönde etkilediğini savunan Arz Yanlı "Askerî Keynesci” yaklaşımdır. Diğer yaklaşım kaynakların daha verimli alanlara yatırılmamasını eleştirerek savunma harcamalarının iktisadi büyümeyi negatif etkilediğini ifade eden Talep Yanlı "Neo-Klasik Teorik" yaklaşımdır. Bazı çalışmalarda ise bu değişkenler arasında herhangi bir ilişkinin olmadığı yönünde sonuçları ortaya koyan bulgulara da rastlanılmaktadır. ${ }^{3}$

Savunma harcamalarının ülkelerin makroekonomik performanslarına yönelik etkilerini araştıran çok sayıda çalışma mevcuttur. Yapılan çalışmalar ağıllıklı olarak savunma harcamaları ile iktisadi büyüme arasındaki ilişkilerin tespitine yönelik yapılmış çalışmalardır. Savunma harcamaları ile iktisadi büyüme arasındaki ilişkilerin tespitine yönelik ilk çalışmalardan biri Benoit (1978)'e aittir. Benoit, aralarında Türkiye'nin de yer aldığ 44 az gelişmiş ülkenin 19501965 dönemine ait verilerini kullanarak yapmış olduğu çalışmada iktisadi büyüme ile savunma harcamaları arasında doğru yönlü bir ilişki tespit etmiştir. Benoit (1978)'in modelinden hareketle çalışmalarını sürdüren Frederikson ve Looney (1983), 24'ü kaynak bolluğu içinde, dokuzu ise

\footnotetext{
${ }^{3}$ Süleyman Özmucur, The Economics of Defense and The Peace Dividend in Turkey, Boğaziçi Üniversitesi Basımevi, İstanbul, 1995, s. 1.
}

\section{1}

Güvenlik Stratejileri

Cilt: 16

Say1: 35 
712

Güvenlik Stratejileri

Cilt: 16

Sayı: 35

kaynak sıkıntısı içinde olan 33 gelişmekte olan ülke üzerinde yaptığı çalışmanın sonunda, kaynak bolluğu yaşayan ülkelerde savunma harcamaları iktisadi büyümeyi olumlu yönden etkilerken, kaynak sıkıntısı yaşayan ülkelerde bu etkinin olumsuz yönde olduğu bulgularına ulaşmışlardır. ${ }^{4}$ Deger ve Smith (1983) ise 50 az gelişmiş ülke üzerinde 1965-1973 dönemi verileri yardımıyla yürüttüğü çalışma sonucunda savunma harcamalarının iktisadi büyüme üzerinde pozitif etkilerinin olduğunu lakin bu etkiden daha fazla olarak tasarruflar üzerinde negatif etkisinin varlığını tespit etmişlerdir. ${ }^{5}$ Biswas ve Ram (1986), 1960-1970 ve 1970-1977 dönemi verileriyle 58 gelişmekte olan ülke için yürüttükleri çalışmanın bulguları neticesinde savunma harcamaları ile iktisadi büyüme arasında istatiksel olarak anlamlı bir ilişki olmadığını tespit etmişlerdir. ${ }^{6}$ Deger (1986), 50 az gelişmiş ve gelişmekte olan 50 ülke üzerinde 1965-1973 yılları verileriyle yapmış olduğu çalışmasının sonucunda, savunma harcamalarının gelişmekte olan ülkeler için iktisadi büyümeyi olumlu etkilediğini fakat çalışma bir bütün olarak ele alındığında savunma harcamalarının iktisadi büyüme hızını azalttığı bulgularına erişmiştir. ${ }^{7}$ Joerding (1986), 57 gelişmekte olan ülkenin 1962-1977 dönemine ait veriler yardımıyla yaptığı çalışmada iktisadi büyümeden savunma harcamalarına doğru tek yönlü bir nedensellik ilişkisi tespit etmiştir. ${ }^{8}$ Gyimah-Brempong (1989), 39 Sahraaltı Afrika ülkesine ait 1973-1983 dönemlerini kapsayan veriler üzerinde yapmış olduğu çalışma neticesinde savunma harcamaları ile iktisadi büyüme

4 Emile Benoit, "Growth and Defense in Developing Countries", Economic Development and Cultural Change, 1978, 26(2), 271-280.

${ }^{5}$ Saadet Deger ve Ron Smith, "Military Expenditure and Growth in Less Developed Countries", Journal of Conflict Resolution, 1983, 27(2), 335-353.

${ }^{6}$ Basudeb Biswas ve Rati Ram, "Military Expenditures and Economic Growth in Less Developed Countries: An Augmented Model and Further Evidence", Economic Development and Cultural Change, 1986, 34(2), 361-372.

7 Saadet Deger, "Economic Development and Defense Expenditure", Economic Development and Cultural Change, 1986, 35(1), 179-196.

8 Wayne H. Joerding, "Economic Growth and Defense Spending: Granger Causality. Journal of Development Economics, 1986, Cilt: 21(1), 35-40. 
arasında pozitif yönlü bir ilişki olduğu yönünde bulgulara ulaşmıştır. ${ }^{9}$ Chowdhury (1991) tarafindan yapılan çalışmada ise 55 gelişmekte olan ülkenin 1961-1987 yıllarına ait verilerden hareketle yapılan çalışmada 15 ülke için savunma harcamalarından iktisadi büyümeye tek yönlü, yedi ülkede iktisadi büyümeden savunma harcamalarına tek yönlü, üç ülkede çift yönlü nedensellik tespit edilmiştir. ${ }^{10}$ Ayrıca diğer 30 ülke için herhangi bir nedenselliğe rastlanamamıştır. LaCivita ve Frederiksen (1991) ikilisi 21 ülke için 1952-1982 dönemi verilerini kullanarak yaptıkları çalışma sonunda savunma harcamaları ile iktisadi büyüme arasında bir ilişkinin olduğunu tespit etmişlerdir. ${ }^{11}$ Payne ve Ross (1992)'da ABD'nin 1960-1980 dönemi verileri yardımıyla yürüttükleri çalışmada, savunma harcamaları ile ekonomik performans arasında bir nedensellik olmadığını tespit etmişlerdir. ${ }^{12}$ Yine Mintz ve Stevenson (1995) 103 ülkenin 1950-1985 dönemi verilerini kullanarak yaptıkları çalışmaları sonucunda çoğu ülke için savunma harcamalarının iktisadi büyüme üzerinde etkisinin anlamsız olduğu ortaya çıkmıştır. ${ }^{13}$ Dunne ve Vougas (1999) Güney Afrika’nın 1961-1995 dönemini ele alarak yürüttüğü çalışmada savunma harcamalarının iktisadi büyüme üzerinde negatif bir etkisi olduğunu sonucuna varmışlardır. ${ }^{14}$ Yunanistan özelinde çalışma yürüten Kollias ve Makrydakis (2000), 1955-1993

9 Kwabena Gyimah-Brempong, "Defense Spending and Economic Growth in Subsaharan Africa: An Econometric Investigation”, Journal of Peace Research, 1989, Cilt: 26(1), 79-90.

${ }^{10}$ Abdur R. Chowdhury, "A Casual Analysis of Defense Spending and Economic Growth", The Journal of Conflict Resolution, 1991, Cilt: 35(1), 80-97.

11 Charles J. LaCivita ve Peter C. Frederiksen, "Defense Spending and Economic Growth an Alternative Approach to The Causality Issue", Journal of Development Economics, 1991, Cilt: 35(1), 117-126.

12 James E. Payne ve Kevin L. Ross, "Defense Spending and The Macroeconomy", Defence Economics, 1992, Cilt: 3(2), 161-168.

13 Alex Mintz ve Randolph T. Stevenson, "Defense Expenditures, Economic Growth and The Peace Dividend: A Longitudinal Analysis of 103 Countries", Journal of Conflict Resolution, 1995, Cilt: 39(2), 283-305.

${ }^{14}$ Paul Dunne ve Dimitrios Vougas, "Military Spending and Economic Growth in South Africa: A Causal Analysis”, Journal of Conflict Resolution, 1999, Cilt: 43(4), 521-537.

\section{3}

Güvenlik Stratejileri

Cilt: 16

Say1: 35 
714

Güvenlik Stratejileri

Cilt: 16

Sayı: 35

dönemini kapsayan veriler yardımıyla savunma harcamaları ile iktisadi büyüme arasında herhangi bir nedensellik ilişkisi tespit edememişlerdir. ${ }^{15}$ Diğer bir çalışma ise iki komşu ülke olan Türkiye ve Yunanistan'ın 1960-1996 dönemi verileriyle savunma harcamaları ile iktisadi büyüme arasındaki ilişkileri tespit etmek amacıyla çalışma yürüten Dunne, Nikolaidou ve Vougas (2001)'a aittir. Yazarlar, Türkiye için savunma harcamalarının iktisadi büyümeyi negatif, Yunanistan için ise savunma harcamalarının iktisadi büyümeyi pozitif yönde etkilediğini tespit etmişlerdir. ${ }^{16}$ Dakurah, Davies ve Sampath (2001), gelişmekte olan 62 ülkeye ait 1975-1995 dönemi verileri ile yaptıkları çalışmanın sonucunda 23 ülkede tek taraflı, yedi ülkede için çift taraflı diğer ülkelerde ise savunma harcamaları ile iktisadi büyüme arasında herhangi bir nedensellik ilişkisi bulunamamıştır. ${ }^{17}$ Yine Türkiye ve Yunanistan'a ait 1960-2001 verilerini kullanan Dritsakis (2004), her iki ülkede iktisadi büyümeden savunma harcamalarına doğru tek yönlü nedensellik ilişkisi bulmuşlardır. ${ }^{18}$ Kollias, Manolas ve Paleologou (2004), 15 AB ülkesinin 1961-2000 dönemini kapsayan verileriyle yaptığı analiz sonucunda savunma harcamaları ile iktisadi büyüme arasında ülkeler açısından farklı sonuçlar ortaya çıkmıştır. Sonuçlara göre bazı ülkelerde değişkenler arasında bir ilişki olmadığı yönünde bulgular elde edilmişken bazı ülkelerde ise iktisadi büyümeden savunma harcamalarına ya tek yönlü ya da çift yönlü nedensellik ilişkisi tespit

15 Christos Kollias ve Stelios Makrydakis, "A Note on the Causal Relationship between Defence Spending and Growth in Greece: 1955-93", Defence and Peace Economics, 2000, 11(1), 173-184.

${ }^{16}$ Paul Dunne, Eftychia Nikolaidou ve Dimitrios Vougas, "Defence Spending and Economic Growth: A Causal Analysis for Greece and Turkey", Defence and Peace Economics, 2001, 12(1), 5-26.

17 Angson Henry Dakurah, Stephen P. Davies ve Rajan. K Sampath, "Defense Spending and Economic Growth in Developing Countries: A Causality Analysis", Journal of Policy Modeling, 2001, 23(6), 651-658.

18 Nikolaos Dritsakis, "Defense Spending and Economic Growth: An Empirical Investigation for Greece and Turkey", Journal of Policy Modeling, 2004, 26(2), 249-264. 
edilmiştir. ${ }^{19}$ Yıldırım ve diğerlerinin (2005), Orta Doğu ülkeleri ile Türkiye'nin 1989-1999 dönemini kapsayan verileriyle yaptığı analizde, savunma harcamalarının iktisadi büyümeyi pozitif yönde etkilediği bulgularına ulaşmışlardır. ${ }^{20}$ Yıldırım ve Öcal (2006) ise iki komşu ülke olan Pakistan ve Hindistan için 1949-2000 dönemini kapsayan veriler yardımıyla yapmış olduğu çalışmada, Pakistan için savunma harcamaları ile iktisadi büyüme arasında herhangi bir ilişki tespit edilemezken Hindistan'da savunma harcamalardan iktisadi büyümeye doğru tek yönlü bir nedensellik tespit edilmiştir. ${ }^{21}$ Yine iki komşu ülke olan Türkiye ve Yunanistan'a ait 1956-2003 verilerini kullanarak bir analiz yürüten Kalyoncu ve Yücel (2006), sadece Türkiye için iktisadi büyümeden savunma harcamalarına doğru tek yönlü nedensellik ilişkisi tespit etmişlerdir. ${ }^{22}$ Silah ithalatının ve savunma harcamalarının iktisadi büyümeye etkisini ela alan Yakovlev (2007), Türkiye'nin de yer aldığ 28 ülkeye ait 1965-2000 dönemi verilerini kullanarak yürüttüğü çalışma sonucunda savunma harcamalarının ve silah ithalatının iktisadi büyümeyi olumsuz yönde etkilediğini saptamıştır. ${ }^{23}$ ABD’nin 1948-2007 dönemi verileri üzerinden bir çalışma yürüten Ateşoğlu (2009), savunma harcamalarının iktisadi büyümeyi pozitif yönde etkilediği yönünde sonuçlar elde etmiştir. ${ }^{24}$ Ateşoğlu (2009) gibi

19 Christos Kollias, George Manolas, ve Suzanna-Maria Paleologou, "Defence Expenditure and Economic Growth in The European Union A Causality Analysis", Journal of Policy Modeling, 2004, 26(5), 553-569.

${ }^{20}$ Jülide Yıldırım, Selami Sezgin ve Nadir Öcal, "Military Expenditure and Economic Growth in Middle Eastern Countries: A Dynamic Panel Data Analysis", Defence and Peace Economics, 2005, 16(4), 283-295.

${ }^{21}$ Jülide Yıldırım ve Nadir Öcal, "Arms Race and Economic Growth: The Case of India And Pakistan", Defence and Peace Economics, 2006, 17(1), 37-45.

22 Hüseyin Kalyoncu ve Fatih Yücel, "An Analytical Approach on Defense Expenditure and Economic Growth: The Case of Turkey and Greece", Journal of Economic Studies, 2006, 33(5), 336-343.

${ }^{23}$ Pavel Yakovlev, "Arms Trade, Military Spending, and Economic Growth", Defence and Peace Economics, 2007, 18(4), 317-338.

${ }^{24}$ H. Sönmez Ateşoğlu, "Defense Spending and Aggregate Output in The United States", Defence and Peace, 2009, 20(1), 21-26. 
716

Güvenlik Stratejileri

Cilt: 16

Sayı: 35

ABD ekonomisinin 1954-2005 dönemi için çalışma yürüten Heo (2010) ise Ateşoğlu (2009)'un bulgularının aksine ABD'de savunma harcamaları ile iktisadi büyüme arasında anlamlı bir ilişkiye rastlamamıştır. ${ }^{25}$ Başar ve Unlu (2012), 36 ülkenin 1997-2004 dönemi verileriyle yaptığ1 çalışma sonucunda savunma harcamaları ile iktisadi büyüme arasında negatif yönlü bir ilişkinin olduğunu gözlemlemişlerdir. ${ }^{26} \mathrm{Na}$ ve $\mathrm{Bo}$ (2013) ise Bangladeş, Hindistan, Pakistan, Nepal ve Sri Lanka için 1990-2006 yılları verilerini kullanarak yaptığı çalışma sonucunda savunma harcamalarının iktisadi büyümeyi olumsuz etkilediğine dair bulgular elde etmişlerdir. ${ }^{27}$ Dunne ve Tian (2013)'da bir önceki çalışmaya benzer bir sonuç elde etmiştir. Yazarlar 106 ülkede 1988-2010 dönemi verileri yardımıyla yaptıkları analiz sonuçlarında kısa ve uzun dönemde savunma harcamalarının iktisadi büyümeyi olumsuz yönde etkilediğini tespit etmişlerdir. ${ }^{28}$ Duyar ve Koçoğlu (2014), altı Sahraaltı Afrika ülkesi için 1990-2012 dönemi verileri yardımıyla yaptığ 1 çalışmada, savunma harcamaların iktisadi büyüme üzerinde pozitif bir etkiye sahip olduğunu saptamışlardır. ${ }^{29}$ Korkmaz (2015), 10 Akdeniz ülkesi için 2005-2012 dönemlerini kapsayan çalışmasında savunma harcamalarının iktisadi büyüme negatif yönde etkilediğini tespit etmişlerdir. ${ }^{30}$ Türkiye ve ABD'nin 1961-2015 yılları verileri ile çalışan

${ }^{25}$ Uk Heo, "The Relationship between Defense Spending and Economic Growth in The United States", Political Research Quarterly, 2010, 63(4), 760-770.

${ }^{26}$ Selim Başar ve Serkan Künü, "Savunma Harcamalarının İktisadi Büyümeye Etkisi”, Sosyal Bilimler Enstitüsü Dergisi, 2012, 10, 1-30.

${ }^{27}$ Hou Na ve Chen Bo, "Cooperation for a Peaceful and Sustainable World Part 2: Military Expenditure and Economic Growth in South Asia", Contributions to Conflict Management, Peace Economics and Development, 2013, 20, 213-223.

28 Paul Dunne ve Nan Tian, "Military Expenditure, Economic Growth and Heterogeneity", Defence and Peace Economics, 2013, 26(1), 15-31.

${ }_{29}$ Metin Duyar ve Mustafa Koçoğlu, "Askerî Harcamaların Ekonomik Büyüme Üzerine Etkisi; Sahra Altı Afrika Örneği”, Uluslararası Sosyal Araştırmalar Dergisi, 2014, 7(33), 703-722.

${ }^{30}$ Suna Korkmaz, "The Effect of Military Spending on Economic Growth and Unemployment in Mediterranean Countries", International Journal of Economics and Financial Issues, 2015, 5(1), 273-280. 
Korkmaz ve Bilgin (2017), ABD'de iktisadi büyüme ile savunma harcamaları arasında bir nedensellik ilişkisi tespit edememişlerdir. Fakat Türkiye için değişkenler arasında çift yönlü bir nedensellik ilişkisi tespit etmişlerdir. ${ }^{31}$ Tuncay (2017), Türkiye, Tunus, Yunanistan, Bulgaristan, Mısır, Azerbaycan, İran ve İsrail'in bulunduğu 7 ülkenin 1996-2014 dönemi verileri ile yürüttüğü çalışmanın sonuçlarına göre savunma harcamaları ile iktisadi büyüme arasındaki negatif yönlü bir ilişki tespit etmiştir. ${ }^{32}$ Yantur ve Gürson (2019) ise ABD, Fransa ve Japonya'nın 1960-2017 dönemine ait çalışma sonucunda ABD'de savunma harcamalarının iktisadi büyüme üzerinde herhangi bir etkisi saptanmazken, Fransa ve Japonya için olumlu sonuçlar elde edilmiştir. Ayrica uzun dönemde ABD, Fransa ve Japonya ekonomilerinde değişkenler arasında çift yönlü nedensellik ilişkisi tespit edilmiştir. ${ }^{33}$

Savunma harcamaları ile iktisadi büyüme arasındaki ilişkileri Türkiye özelinde yürüten bazı çalışmalarda mevcuttur. Ele alacağımız bu çalışmaların ilki Kollias (1997)'a aittir. Kollias (1997), Türkiye'nin 1954-1993 yılları arasındaki verilerini kullanarak yaptığı çalışmada iktisadi büyüme ile savunma harcamaları arasında herhangi bir nedensellik ilişkisi tespit edememiştir. ${ }^{34}$ Sezgin (1997) ise 1950-1993 yılları arasındaki veriler yardımıyla Kollias (1997)'ın çalışmasının sonuçlarının aksine savunma harcamalarının iktisadi büyüme üzerinde pozitif bir etki ortaya çıkarttığını tespit etmiştir. ${ }^{35}$ Sezgin yine 2001 yılında

\footnotetext{
${ }^{31}$ Özge Korkmaz ve Tuba Bilgin, “Askerî Harcamalar ile Ekonomik Büyüme Arasındaki İlişki: Türkiye ve Amerika Birleşik Devletleri'nin Karşılaştırmalı Analizi”, International Journal of Economic \& Administrative Studies, 2017, 18, 289-316.

32 Özhan Tuncay, "Finansal Serbestleşme Sonrası Dönem Savunma Harcamalarının Ekonomik Analizi”, Uluslararası Ekonomik Araştırmalar Dergisi, 2017, 3(1), 23-37.

${ }^{33}$ Pelin Yantur ve Ali Poyraz Gürson, "Savunma Harcamaları ve Ekonomik Büyüme Üzerine Araştırma: ABD, Japonya ve Fransa Örneği", Insan ve Toplum Bilimleri Araştırmaları Dergisi, 2019, 8(1), 163-182.

${ }^{34}$ Christos Kollias, "Defence Spending and Growth in Turkey 1954-1993: A Causal Analysis", Defence and Peace Economics, 1997, 8(2), 189-204.

35 Selami Sezgin, "Country survey X: Defence spending in Turkey", Defence and Peace Economics, 1997, 8(4), 381-409.
}

\section{7}

Güvenlik Stratejileri

Cilt: 16

Say1: 35 
yürüttüğü diğer çalışmada 1956-1994 yılları arasındaki verileriyle

Güvenlik

Stratejileri

Cilt: 16

Say1: 35 yaptığı çalışmada önceki sonucuna benzer olarak savunma harcamalarının iktisadi büyümeyi pozitif yönde etkilediğini tespit etmiştir. ${ }^{36}$ Karagöl ve Palaz (2004) ise 1955-2000 dönemi verileri ile yürüttüğü çalışmanın sonucunda savunma harcamalarından iktisadi büyümeye doğru tek yönlü negatif bir ilişki bulmuştur. ${ }^{37}$ Görkem ve Işık'ın (2008) ise 1968-2006 dönemi verilerini kullandığı çalışmada savunma harcamaları ve iktisadi büyüme arasında herhangi bir nedensellik ilişkisi saptayamamışlardır. ${ }^{38}$ Karagianni ve Pempetzoglu (2009)'da 1949-2004 dönemi verileri ile yaptığı analiz sonucunda savunma harcamalarından iktisadi büyümeye doğru tek yönlü nedensellik ilişkisinin olduğunu tespit etmişlerdir. ${ }^{39}$ 1950-2006 dönemini ele alan Yılancı ve Özcan (2010) ise iktisadi büyümeden savunma harcamalarına doğru tek yönlü nedensellik tespit etmişlerdir. ${ }^{40}$ Kaya (2013)'da 19702010 dönemi verileriyle yürüttüğü çalışmasında savunma harcamalarından iktisadi büyümeye doğru nedensellik ilişkisi tespit etmiştir. ${ }^{41}$ Son olarak Topal (2018)'ın 1960-2016 verileri ile yaptığı analizin sonuçlarına göre savunma harcamaları uzun dönemde iktisadi büyümeyi negatif

${ }^{36}$ Selami Sezgin, “An Empirical Analysis of Turkey's Defence-Growth Relationships with a Multi-Equation Model (1956-1994)", Defence and Peace Economics, 2001, 12(1), 69-86.

${ }^{37}$ Erdal Karagöl ve Serap Palaz, "Does Defense Expenditure Deter Economic Growth in Turkey? A Cointegration Analysis", Defence and Peace Economics, 2004, 15(3), 289-298.

${ }^{38}$ Hilal Görkem ve Serkan Işık, "Türkiye'de Savunma Harcamaları ve Ekonomik Büyüme Arasındaki İlişki (1968-2006)”, Marmara Üniversitesi İktisadi ve İdari Bilimler Fakültesi Dergisi, 2008, 25(2), 405-424.

39 Stella Karagianni ve Maria Pempetzoglou, "Defense Spending and Economic Growth in Turkey: A Linear and Non-Linear Granger Causality Approach", Defence and Peace Economics, 2009, 20(2), 139-148.

${ }^{40}$ Veli Yılancı ve Burcu Özcan, "Yapısal Kırılmalar Altında Türkiye İçin Savunma Harcamaları ile GSMH Arasındaki İlişkinin Analizi”, Cumhuriyet Üniversitesi İktisadi ve İdari Bilimler Dergisi, 2010, 11(1), 21-33.

${ }^{41}$ Semanur Soyyiğit Kaya, "Türkiye'de Savunma Harcamalarının İktisadi Etkileri Üzerine Nedensellik Analizi (1970-2010)", Trakya University Journal of Social Science, 2013, 15(2), 17-38. 
yönde etkilemektedir. Fakat 1970'li yılların ortalarından itibaren savunma harcamaları ile iktisadi büyüme arasında herhangi bir nedensellik ilişkisinin kalmadığı yönünde sonuçlar elde etmiştir. ${ }^{42}$

Yapılan bu çalışmalar neticesinde savunma harcamalarının iktisadi büyüme üzerindeki etkilerinin yönü farklılık arz etmekle birlikte net bir kanıya varılamamaktadır. Bunun en önemli sebebi ise çalışmalarda kullanılan yöntem, dönem, ülke ve ülke grubundaki farklılıklardır. Bu ilişkinin yönünün tespitindeki güçlüğün yanı sıra savunma harcamalarının iktisadi büyüme üzerinde meydana getirdiği etkileri göz ardı etmek de mümkün değildir. Bilhassa gelişmiş ve gelişmekte olan ülkelerde yapılan bu harcamalar iktisadi büyüme üzerinde farklı etkiler ortaya çıkarmaktadır. Burada önemli olan husus bu tür harcamaların devlet bütçesinde meydana getirdiği yükü en aza indirgemeye çalışmaktır. Dolayısıyla savunma harcamaları içerisinde önemli yer tutan silah üretimine ve ithaline yapılan harcama kalemi için yerli savunma sanayiine yönelik yatırımların artırılması ve desteklenmesi önem arz ettiği literatürde ifade edilmektedir. Böyle bir durum ise ülke kaynaklarının yurtdışına akışını engelleyip yerli üreticileri üretime ve yatırıma motive etmesi iktisadi büyümeyi hızlandırıcı etki oluşturabileceği vurgulanmıştır.

\section{Veri ve Model}

Türkiye'ye ait Gayri Safi Yurtiçi Hasıla (GSYIH) ve silah ithalatı arasındaki ilişkileri incelediğimiz bu çalışmada 1990-2017 dönemi kapsayan veriler kullanılmaktadır. Bağımlı değişken olan GSYİH'ya ait veriler Dünya Bankası resmî internet sitesinden, bağımsız değişken olan silah ithalatı verileri ise Stockholm International Peace Research Institute (SIPRI) resmi internet sitesinden elde edilmiştir. Silah ithalatı içinde uçak, hava savunma sistemleri, denizaltıya karşı silah sistemleri, zırhlı araçlar, ağır silahlar, motorlar (hava, deniz ve kara vasıtaları), füzeler, sensörler, uydular vb. araç ve teçhizatlar yer almaktadır. Serilerin

\footnotetext{
${ }^{42}$ Mehmet Hanefi Topal, "Türkiye'de Askerî Harcamalar ile Ekonomik Büyüme Arasındaki İlişkinin Bir Analizi (1960-2016)”, Maliye Dergisi, 2018, 174, 175-202.
} 
720

Güvenlik Stratejileri

Cilt: 16

Say1: 35 doğrusal olması ve katsayıların esneklik şeklinde yorumlanabilmesi için değişkenlerin doğal logaritması alınmıştır.

Zaman serisi analizleri yapılırken öncelikle değişkenlerin zaman serisi özellikleri olup olmadığının incelenmesi gerekir. Bu kapsamda, değişkenlere ait zaman serisi grafikleri çizdirilmeli; mevsimsellik, trend, kırılmalar vb. zaman serisi bileşenlerinin olup olmadığı incelenmelidir. Değiş̧kenlere ait grafikler Şekil 1'de görülmektedir.

Şekil 1: Değişkenlere ait Grafikler LGDP
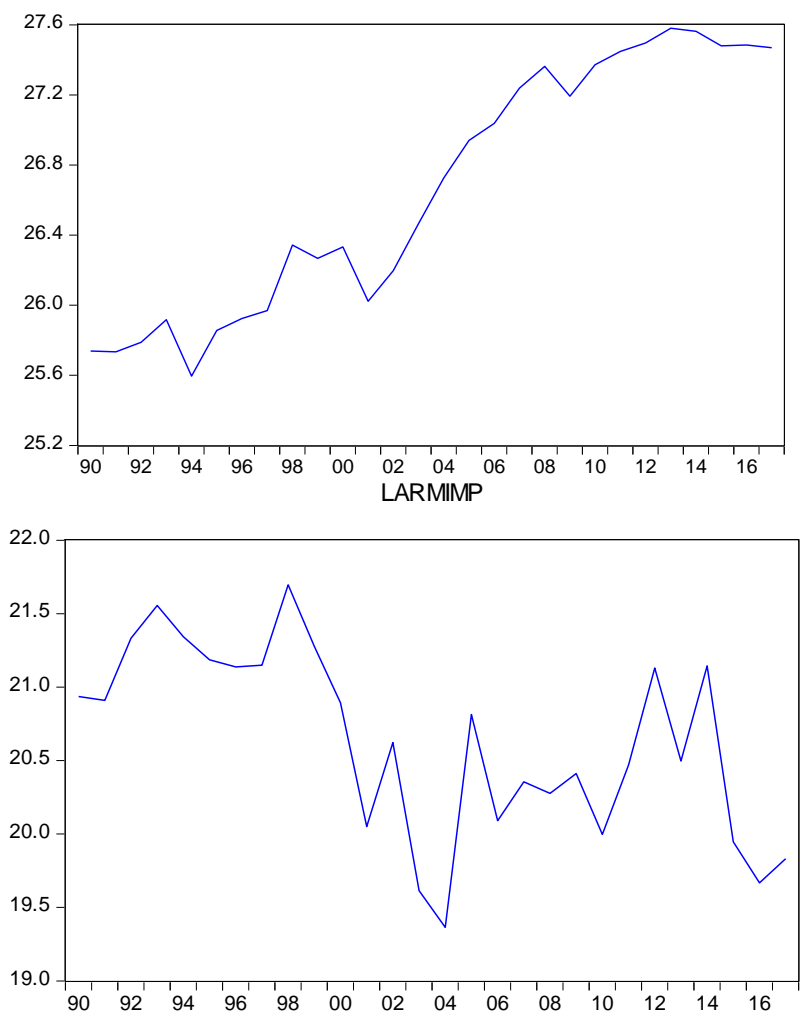
Şekil 1'e bakıldığında ele alınan dönem için her iki değişkende artış eğilimi ve kırılmaların varlığı dikkat çekmektedir. Mevcut olan kırılmaların döneme ait ekonomik ve siyasal gelişmelerin etkisinden kaynaklandığı değerlendirilmektedir. Bu durum göz ardı edilmemesi gereken bir durum olup mevcut kırılmaların değişkenler üzerinde hangi tarihlerde etkili olduğunu tespit etmek gerekmektedir.

Çalışmada değişkenler arasındaki ilişkileri şu şekilde modellenmiștir:

$$
L G D P_{t}=\beta_{0}+\beta_{1} L A R M I M P_{t}+\alpha_{i} \text { Ktrlmalar }+u_{t}
$$

1 nolu modelde belirtilen bağımlı değişken LGDP, GSYIH'n'nın logaritmik dönüștürülmüş halini bağımsız değișken LARMIMP ise silah ithalatını temsil eden değişkenlerdir. Kırılmalar değişkeni ise Bai ve Perron (2003) testinden elde edilen kırılma tarihlerine kukla değişkenlerini, $\alpha_{i}$ ise kukla değişkenlerinin katsayını ifade etmektedir. Değişkenlerin sonunda gösterilmiş olan $t$ indisi değişkenlere ait serilerin zaman serisi olduğunu ifade etmektedir. $\beta_{0}$ modelin sabit terim katsayısını, $\beta_{1}$ ise modelin eğim katsayısını gösterme olup $\beta_{1}$ LARMIMP'deki \%1'lik değişimin LGDP değişkeni üzerinde oluşturacağı değişimi göstermektedir. Modelin hata terimi ise $u_{t}$ 'dir.

\section{Yöntem ve Bulgular}

Silah ithalatının iktisadi büyüme üzerindeki etkilerinin araştırıldığ 1 bu çalışmada değişkenler arasındaki ampirik ilişkiler üç aşamalı bir yolla incelendi. Birinci aşamada çalışmanın bağımlı değişkeni olan LGDP'deki Şekil 1'de görülen kırılmaların anlamlılığ istatistiki olarak Bai ve Perron (2003) ${ }^{43}$ testi kullanılarak test edilmeye çalış1lacaktır. İkinci aşamada tek kırılmalı Augmented Dickey Fuller (ADF) birim kök testiyle değişkenlerin durağanlık düzeyleri incelenecektir.

\footnotetext{
${ }^{43}$ Teste ait detaylı bilgilere Bai ve Perron (2003) çalışmasından ulaşılabilir.
}

\section{1}

Güvenlik Stratejileri

Cilt: 16

Say1: 35 
722

Güvenlik Stratejileri

Cilt: 16

Sayı: 35

Üçüncü ve son aşamada ise Otoregresif Gecikmesi Dağıtılmış Modeline (ARDL) dayalı sınır testi ile değişkenler arasında uzun dönemli ilişkilerin olup olmadığı incelenecektir.

\subsection{Bai ve Perron Yapısal Kırılma Testi}

Şekil 1'e bakıldığında incelenen dönem içinde her iki değiş̧kende kırılmaların olduğunu ve mevcut kırılmaların değişkenler üzerinde hangi tarihlerde etkili olduğunu tespit etmek gerektiğini daha önce de vurgulamıştık. Bağımlı değişkenin LGDP olmasından dolayı sadece bu değişken için kırılma tarihleri araştırılmış ve bu tarihler ARDL modeline eklenmiştir. İşte yapısal kırılmaları tespit edilmesi amacıyla bu çalışmada Bai ve Perron (2003) yapısal kırılma testi yapılmış olup test sonuçları Tablo 1'de görülmektedir.

Tablo 1: Bai ve Perron (2003) Test Sonuçları**

\begin{tabular}{|l|c|c|}
\hline \multicolumn{3}{|c|}{ LGDP } \\
\hline $\begin{array}{c}\text { Kırılma } \\
\text { Testi }\end{array}$ & $\begin{array}{c}\text { Hesaplanan } \\
\text { İstatistik }\end{array}$ & \%5 Kritik Değerler** \\
\hline 0 vs. $1 *$ & 26.69 & 11.47 \\
\hline 1 vs. 2 & 11.32 & 12.95 \\
\hline 2 vs. $3 *$ & 18.14 & 14.03 \\
\hline 3 vs. 4 & 7.68 & 14.85 \\
\hline 4 vs. 5 & 4.96 & 15.29 \\
\hline
\end{tabular}

* Anlamlı kırılma sayısını göstermektedir.

** Sabitli ve trend model dikkate alınarak hesaplanmıştır.

LGDP değişkeninin anlamlı kırılma tarihleri: 1994, 2001, 2007

Tablo 1'de görüldüğü üzere LGDP değişkeninde 1994, 2001 ve 2007 tarihlerinde anlamlı yapısal kırılmaların olduğu görülmektedir. $\mathrm{Bu}$ tarihler Türkiye'nin ciddi iktisadi krizlerle uğraştı̆̆ 1 dönemlerdir. Özellikle 1994 yılında bütçe ve cari açık çok ciddi düzeylere ulaşmış ve mevcut hükümetin özelleştirme planları da istenildiği şekilde işlememesi piysaların iyice daralmasına yol açmıştı. Bu süreçle birlikte 
ülkeden sermaye çıkışlarının hızlanması doların yaklaşık 14 kat artmasına ve krizin körüklenmesine sebep olmuştu. 2001 yılında Türkiye'de Millî Güvenlik Kurulu (MGK)' da yaşanan siyasal gerginlikle başlayan 2001 krizi de 1994 krizine benzer bir şekilde daralmış olan piyasadan sermaye çıkışlarıyla körüklenmiştir. Özellikle bankacılık sektöründe başlayan kriz reel sektörün tamamına yayılan bir etki meydana getirmiştir. 2007 yılı ise ABD merkezli başlayıp küresel çapta bir krize dönüşecek 2008 krizinin başlangıcıdır.

\subsection{Tek Kurılmalı ADF Birim Kök Testi}

Zaman serisi analizlerinde öncelikle modele dâhil edilen değişkenlere ait serilerin durağan olup olmadığı araştırılmalıdır. $\mathrm{Bu}$ yapılmadığı takdirde yani durağan olmayan serilerle yapılacak testler güvenilir olmayan sonuçları ve sahte regresyon sorununu ortaya çıkarmaktadır. $\mathrm{Bu}$ problemi önlemek amacıyla serilerin durağanlığını sınamak amacıyla geliştirilmiş olan birçok birim kök testi mevcuttur. Çalışmada tek kırılmalı birim kök testi neticesinde değişkenlerin bütünleşme dereceleri tespit edilmek istenmiş̧ir. Tablo 2'de çalışmada yer alan değiş̧enlere ait tek kırılmalı ADF birim kök testi sonuçları görülmektedir.

Tablo 2: Tek Kırılmalı ADF Birim Kök Testi*

\begin{tabular}{|l|c|c|c|}
\hline \multicolumn{1}{|c|}{ Değişken Adı } & $\begin{array}{c}\text { Hesaplanan } \\
\text { t-istatistik Değeri }\end{array}$ & Olasılık Değeri & Kırılma Tarihi \\
\hline LGDP & -3.523 & 0.802 & 2004 \\
\hline LLGDP & $\mathbf{- 7 . 2 9 0 * *}$ & $\mathbf{0 . 0 0 1}$ & $\mathbf{2 0 0 1}$ \\
\hline LARMIMP & -4.474 & 0.248 & 2000 \\
\hline LLARMIMP & $\mathbf{- 8 . 9 7 1 * *}$ & $\mathbf{0 . 0 0 1}$ & $\mathbf{2 0 0 5}$ \\
\hline
\end{tabular}

* Sabilti ve trendli modelde Sabitte ve trende kırılmalar dikkate alınarak birim kök testi yapılmıştır.

** \%1 anlamlılık düzeyine göre durağanlığ 1 ifade etmektedir.

Tablo 2'deki tek kırılmalı ADF birim kök testi sonuçlarında değişkenlerin farkları I(1) alındığı takdirde \%1 istatistiksel anlamlılık düzeyinde durağan hale gelmektedir. Ayrıca LGDP değişkeni için 
724

Güvenlik Stratejileri

Cilt: 16

Sayı: 35

2001 ve 2004 'de, LARMIMP için de 2000 ve 2005 'de kırılmaların olduğu tespit edilmiştir. Mevcut kırılmalar özellikle Türkiye'nin 1999 yılında başlayıp 2000'li yılların ortalarına kadar süregelen siyasi ve ekonomik kriz dönemlerine denk geldiği görülmektedir.

\subsection{ARDL Sinır Testi ve Tanımlayıcı Ístatistikler}

ARDL Sinır testi, Pesaran, Shin and Smith $(2001)^{44}$ tarafindan geliştirilmiş değişkenler arasındaki uzun dönemleri ilişkileri inceleyen bir testtir. Ayrıca ARDL Sınır testi diğer eşbütünleşme testlerine nazaran farklı düzeylerde durağan değişkenler arasındaki uzun dönemli ilişkileri de inceleyebilmektedir. Fakat bu testte öncelikle bağımlı değişkenin $I(1)$ ve diğer değişkenlerin en fazla $I(1)$ seviyesinde durağan olması gerekmektedir.

$$
\begin{aligned}
L G D P_{t}=\Theta_{0}+ & \sum_{i=1}^{m} \Theta_{1 i} L G D P_{t-i} \\
& +\sum_{i=0}^{n} \Theta_{2 i} L A R M I M P_{t-i}+\alpha_{i} \text { Kurlmalar } \\
& +e_{t}
\end{aligned}
$$

2 nolu model çalışmada yer alan değişkenlere ait bir ARDL modeli eşitliğidir. Modelde bulunan $\Theta^{\prime}$ lar bağımsız değişkenlerin katsayı matrisini sembolize etmektedir. Model içindeki m, $n$ ve 1 sembolleri ise değişkenlerin alabileceği farklı gecikme sayılarını göstermektedir. Ayrıca model içinde yer alan $i$ ise gecikme sayısını, $e_{t}$ ise modelin hata terimini ifade etmektedir. Modeldeki gecikme sayıları Akaike Bilgi Kriteri (AIC) vasıtasıyla belirlenmiştir. Ayrıca bu çalışma için LGDP değişkeninde tespit edilen kırılmalar ARDL modeline dışsal değişken şeklinde eklenerek analizler gerçekleştirilmiştir.

${ }^{44}$ M. Hashem Pesaran, Yongcheol Shin ve Richard J. Smith, "Bounds Testing Approaches to The Analysis of Level Relationships", Journal of Applied Econometrics, 2001, 16(3), 289-326. 
Analizler neticesinde uygun modelin ARDL $(1,1)$ modeli olduğu saptanmış ve modelin uygun olup olmadı̆̆ının sınanması amaciyla tanımlayıcı testler yapılmıştır. Tablo 3'de $\operatorname{ARDL}(1,1)$ modelinin tahmin ve tanımlayıcı testlere ait sonuçlar yer almaktadır.

Tablo 3: ARDL $(1,1)$ Model Tahmini

\begin{tabular}{lcccr}
\hline Değişken & Katsayı & Standart Hata & t-istatistik & \multicolumn{1}{c}{ Olasılık } \\
\hline LGDP (-1) & $\mathbf{0 . 8 8 9 *}$ & $\mathbf{0 . 0 3 9}$ & $\mathbf{2 2 . 7 2 2}$ & $\mathbf{0 . 0 0 0 1}$ \\
\hline LARMIMP & -2.020 & 0.047 & -0.436 & 0.6669 \\
\hline LARMIMP (-1) & -0.066 & 0.047 & -1.406 & 0.1750 \\
\hline D1994 & $\mathbf{- 0 . 4 1 7 ^ { * }}$ & $\mathbf{0 . 1 2 2}$ & $\mathbf{- 3 . 4 1 8}$ & $\mathbf{0 . 0 0 2 7}$ \\
\hline D2001 & $\mathbf{- 0 . 4 3 0 *}$ & $\mathbf{0 . 1 2 2 8}$ & $\mathbf{- 3 . 5 0 6}$ & $\mathbf{0 . 0 0 2 2}$ \\
\hline D2007 & 0.111 & 0.118 & 0.938 & 0.3590 \\
\hline C & $\mathbf{4 . 8 4 1 *}^{*}$ & $\mathbf{1 . 8 1 7}$ & $\mathbf{2 . 6 6 3}$ & $\mathbf{0 . 0 1 4 9}$ \\
\hline
\end{tabular}

Tanımlayıcı İstatistikler

\begin{tabular}{lcc}
\hline Test & $\begin{array}{c}\text { Hesaplanan } \\
\text { İstatistik }\end{array}$ & Olasılık \\
\hline $\begin{array}{l}\text { Breusch-Godfrey } \\
\text { Otokorelasyon }\end{array}$ & 1.215 & 0.544 \\
\hline $\begin{array}{l}\text { Breusch-Pagan-Godfrey } \\
\text { Değişen Varyans }\end{array}$ & 3.133 & 0.719 \\
\hline Jargue-Bera Normalillik & 0.514 & 0.773 \\
\hline Ramsey RESET & 0.967 & 0.337 \\
\hline
\end{tabular}

*\%5 anlamlılık düzeyine göre anlamlılığ ifade etmektedir.

Tablo 3'de ARDL $(1,1)$ modeli için otokorelasyon ve değişen varyans sorunları tespit edilmemiştir. Ayrıca hata terimlerinin normal dağıldığı ve modelde herhangi bir problem rastlanmadığı yönünde sonuçlar elde edilmiştir.

ARDL $(1,1)$ modeli için mevcut katsayıların istikrarlı olup olmadığına yönelik CUSUM ve CUSUMQ analizleri yapılmıştır. Şekil 2'de de görüleceği üzere CUSUM ve CUSUMQ'ler \%5 güven 
726

Güvenlik Stratejileri

Cilt: 16

Say1: 35 aralıkları içinde olup ele alınan dönem için elde edilen katsayıların istikrarlı olduğu sonucuna ulaşılmaktadır.

Şekil 2: Katsayı İstikrarlıık Test Sonuçları
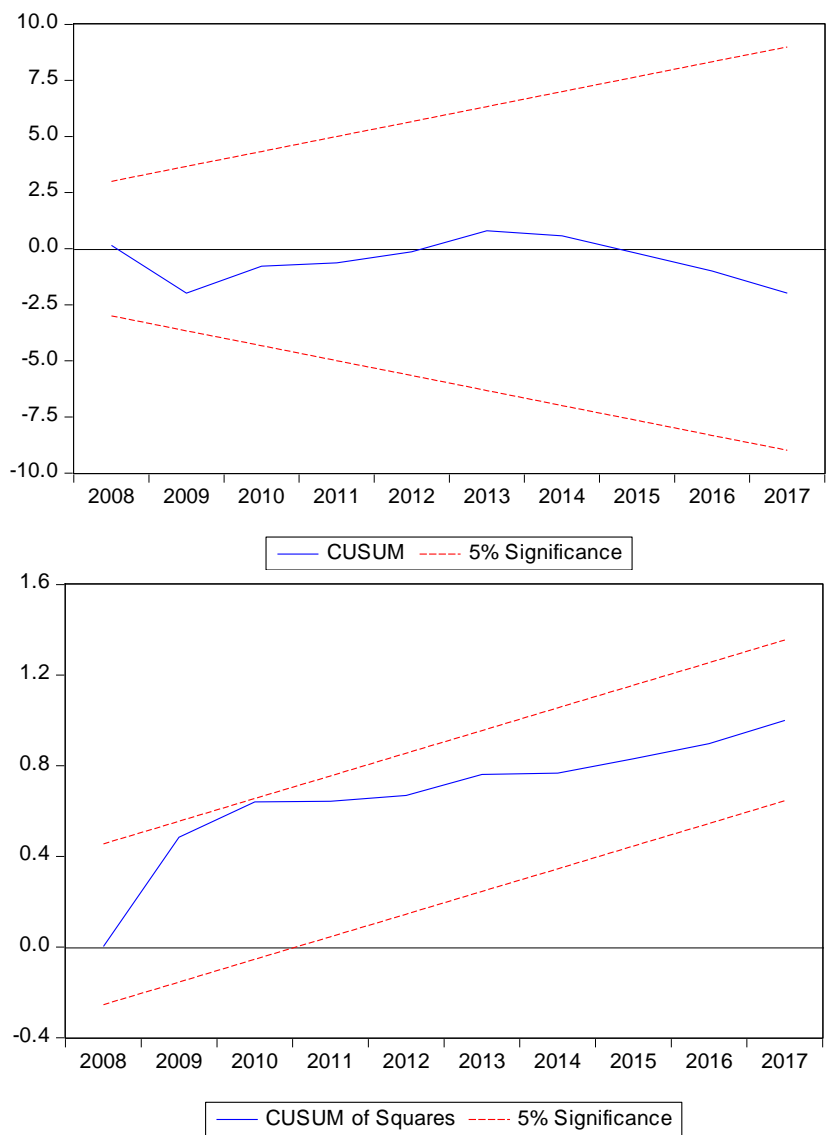

ARDL modeli belirlendikten sonra yapılması gerek ilk iş sınır testi için eşitliği oluşturmaktır. 


$$
\begin{aligned}
\Delta L G D P_{\mathrm{t}}=\theta_{0}+\sum_{\mathrm{i}=1}^{m} & \theta_{1 \mathrm{i}} \Delta L G D P_{\mathrm{t}-\mathrm{i}} \\
& +\sum_{\substack{\mathrm{i}=0 \\
n}}^{n} \theta_{2 \mathrm{i}} \Delta L A R M I M P_{\mathrm{t}-\mathrm{i}}+\theta_{\mathrm{a}} L G D P_{\mathrm{t}-\mathrm{i}}+\theta_{4} \text { LARMIMP }_{\mathrm{t}-\mathrm{i}} \\
& +\alpha_{\mathrm{i}} \text { Kinlmalar }+\mathrm{\theta}_{1 \mathrm{t}} \text { (3) }
\end{aligned}
$$

\section{7}

Güvenlik Stratejileri

Cilt: 16

Say1: 35

Değişkenler arasındaki uzun dönemli ilişkileri saptamak için yapılan sınır testi için oluşturulan eşitlik 3 no'lu eşitlikte olduğu gibi gösterilmiş olup bu teste ait hipotezler aşağıda ifade edildiği gibidir;

\section{$H_{0}: \theta_{3}=\theta_{4}=0$ (eşbütünleşme yoktur),}

$H_{1}$ : En az bir $\theta \neq 0$ (eşbütünleşme vardır).

Hipotezler, Wald $\mathrm{F}$ istatistiği ile modelde bulunan $\theta_{3}=\theta_{4}=0$ katsayılarının eşanlı olarak sıfira eşit olup olmadığı sınanarak sınır testine ait istatistik değeri saptanmaktadır. Hipotezlere yönelik karar verebilmek için saptanan bu istatistik değeri Pesaran, Shin and Smith makalesinde ${ }^{45}$ belirtilen alt sınır I (0) ve üst sınır I (1) değerleriyle kıyaslanmaktadır. Hesaplanan istatistik değeri I (1) kritik değerinden büyükse $\mathrm{H}_{0}$ reddedilir ve değişkenler arasında uzun dönemli ilişkilerin olduğu ifade edilebilir.

Tablo 4: ARDL Sınır Testi Sonuçları

\begin{tabular}{|c|c|c|c|}
\hline $\mathbf{K}$ & F istatistiği & \multicolumn{2}{|c|}{ \%1 Kritik Değerler } \\
\hline \multirow{2}{*}{1} & \multirow{2}{*}{$\mathbf{7 . 6 9 9}^{*}$} & $\mathrm{I}(0)$ & $\mathrm{I}(1)$ \\
\cline { 3 - 4 } & & 4.94 & 5.58 \\
\hline
\end{tabular}

\footnotetext{
${ }^{45}$ M. Hashem Pesaran, Yongcheol Shin ve Richard J. Smith, "Bounds Testing Approaches to The Analysis of Level Relationships", Journal of Applied Econometrics, 2001, 16(3), s. 300 .
} 
728

Güvenlik Stratejileri

Cilt: 16

Sayı: 35

Tablo 4'de ARDL sınır testi sonuçlarına göre elde edilen F istatistik değeri (7.699), I (1) kritik değerinden (5.58) büyük olduğu için $\mathrm{H}_{0}$ hipotezi reddedilmektedir. Bu sonuç LARMIMP değişkeninin LGDP değişkenini uzun dönemde etkilediği anlamına gelmektedir. $\mathrm{Bu}$ bulguyu dikkate alarak Türkiye'nin silah ithalatının uzun dönemde GSYİH'ya etkisinin olduğu söylenebilir. Bu aşamaların ardından hata düzeltme mekanizmasının çalışıp çalışmadığı ve değişkenler arasında uzun ve kısa dönemde nasıl bir etkileşim olduğu sınanmalıdır. Hata düzeltme mekanizmasının çalışıp çalışmadığı 4 no'lu model yardımıyla test edilmektedir.

$$
\begin{aligned}
\Delta L G D P_{t}=\theta_{0}+ & \sum_{i=1}^{m} \theta_{1 i} \Delta L G D P_{t-i} \\
& +\sum_{i=0}^{n} \theta_{2 i} \Delta L A R M I M P_{t-i}+\theta_{3} E_{t} M_{t-1} \\
& +e_{2 t}
\end{aligned}
$$

4 no'lu model içinde bulunan ECM (-1)'ye ait katsayının 0 ile -1 arasında ve istatistiki olarak anlamlı oluşu değişkenler arasındaki dengesizliklerin kısa dönemde düzeldiğini göstermektedir. Tablo 5'de hata düzeltme modeline ait kısa ve uzun dönem sonuçları yer almaktadır.

Tablo 5: Kısa Dönem ve Uzun Dönem Katsayıları

Kısa Dönem Katsayıları ve Hata Düzeltme Modeli

\begin{tabular}{lrrrr}
\hline Değişken & \multicolumn{1}{c}{ Katsayı } & \multicolumn{1}{c}{ Standart Hata } & t-istatistik & Olasılık \\
\hline$\Delta$ LARMIMP & -0.014 & 0.039 & -0.378 & 0.709 \\
\hline$\Delta$ D1994 & $\mathbf{- 0 . 4 6 3 *}$ & $\mathbf{0 . 0 8 3}$ & $\mathbf{- 5 . 5 2 6}$ & $\mathbf{0 . 0 0 1}$ \\
\hline$\Delta$ D2001 & $\mathbf{- 0 . 4 0 5 *}$ & $\mathbf{0 . 0 8 8}$ & $\mathbf{- 4 . 5 6 2}$ & $\mathbf{0 . 0 0 1}$ \\
\hline$\Delta$ D2007 & 0.072 & 0.076 & 0.956 & 0.350 \\
\hline ECM (-1) & $\mathbf{- 0 . 1 0 4 *}$ & $\mathbf{0 . 0 2 1}$ & $\mathbf{- 4 . 7 8 2}$ & $\mathbf{0 . 0 0 1}$ \\
\hline
\end{tabular}


Türkiye'de Silah İthalatının İktisadi Büyüme Üzerine Etkisi

\begin{tabular}{lrrrr}
\hline \multicolumn{5}{c}{ Uzun Dönem Katsayıları } \\
\hline Değişken & Katsayı & Standart Hata & t-istatistik & Olasılık \\
\hline$\Delta$ LARMIMP & $\mathbf{- 0 . 7 8 8 *}$ & $\mathbf{0 . 3 7 7}$ & $\mathbf{- 2 . 0 8 8}$ & $\mathbf{0 . 0 4 9}$ \\
\hline$\Delta$ D1994 & $\mathbf{- 3 . 7 6 9 *}$ & $\mathbf{1 . 6 7 7}$ & $\mathbf{- 2 . 2 4 6}$ & $\mathbf{0 . 0 3 6}$ \\
\hline$\Delta$ D2001 & $\mathbf{- 3 . 8 9 1 *}$ & $\mathbf{1 . 6 2 6}$ & $\mathbf{- 2 . 3 9 2}$ & $\mathbf{0 . 0 2 6}$ \\
\hline$\Delta$ D2007 & 1.005 & 1.115 & 0.901 & 0.378 \\
\hline C & $\mathbf{4 3 . 7 4 7 *}$ & $\mathbf{7 . 8 2 5}$ & $\mathbf{5 . 5 9 0}$ & $\mathbf{0 . 0 0 1}$ \\
\hline
\end{tabular}

*\%5 anlamlılık düzeyine göre anlamlılı̆̆g ifade etmektedir.

Tablo 5'de görüldüğü üzere kısa dönem için LARMIMP değişkeni ile LGDP değişkeni arasında istatistiki olarak anlamlı bir ilişki tespit edilememiştir. Uzun dönemde ise LARMIMP değişkeninin LGDP üzerinde istatistiki olarak anlamlı bir etkisi bulunmaktadır. Uzun dönemde LARMIMP değişkeninde meydana gelen \%1'lik artış LGDP değişkenini yaklaşık \%0.78 oranında azaltmaktadır. Ayrıca mevcut sonuçlara göre ECM (-1) katsayısı 0 ile -1 arasında ve istatistiki olarak anlamlıdır. $\mathrm{Bu}$ katsayının anlamlı olması modelde hata düzeltme mekanizmasının çalıştığını yani kısa dönemdeki sapmaların uzun dönemde dengeye geldiğini göstermektedir.

\section{Sonuç}

Savunma harcamalarının iktisadi büyümeye olan etkisi literatür taramasından da anlaşılacağı üzere bu harcamaların şekli, hükümetlerin uygulamış oldukları politikalar, ülkenin ekonomik gelişmişlik seviyesi ve ele alınan dönem gibi çeşitli faktörlere bağlı olarak değişmektedir. Savunma harcamaları Brzoska'nın çalışmasında belirtiği gibi birçok harcama kaleminden oluşmaktadır. ${ }^{46}$ Savunma harcama kalemleri içerisinde ekonomiyi olumsuz yönde etkileme potansiyeli olan en önemli harcama kalemi ise silah üretimine ve ithalatına yapılan harcamalardır.

\footnotetext{
${ }^{46}$ Michael Brzoska, "World Military Expenditures", Keith Hartley ve Todd Sandler, (ed.), Handbook of Defense Economics, Elsevier, Amsterdam, 1995, s. 48-49.
} 
730

Güvenlik Stratejileri

Cilt: 16

Say1: 35

Türkiye'nin silah ithalatının iktisadi büyüme üzerindeki etkisini 19902017 yılları için araştıran bu çalışma silah ithalatının iktisadi büyüme üzerinde kısa dönemde herhangi bir etkisi olmadığını fakat uzun dönemde silah ithalatının iktisadi büyümeyi negatif yönde etkilediğine dair sonuçlar ortaya koymaktadır. Bilhassa gelişmekte olan ülkelerin savunma harcamaları daha çok ithalat yoluyla tedarik edilmektedir. Dolayısıyla bu tür gelişmişlik seviyesine sahip olan ülkelerin savunmaya yönelik yapacakları harcamalar ödemeler dengesini bozucu ve iktisadi büyümeyi engelleyici nitelik taşımaktadır. Bu çalışma da gelişmekte olan ülkeler içerisinde yer alan Türkiye'nin silah ithalatının iktisadi büyümeyi negatif etkilediği yönünde bulguları ortaya koymaktadır.

Silahların ithal edilmesi özellikle gelişmekte olan ülkeler için değerli döviz rezervlerinin tahliyesine neden olmaktadır. Böyle bir durum ise silah ithalatının firsat maliyetinin kendisinden yüksek olabileceğini göstermektedir. Türkiye gibi savunma harcamalarını azaltamayacak bir coğrafyada bulunan bir ülkenin mevcut kaynaklarını dışa aktarmayı önleyici bazı tedbirler alması gerekmektedir. $\mathrm{Bu}$ tedbirlerin en öncelikli olanı yerli bir savunma sanayi alt yapısının teşkil edilmesi olmalıdır. Genel olarak değerlendirildiğinde güçlü bir yerli savunma sanayi sektörünün varlığı iki açıdan gereklidir. Bunların birincisi ulusal güvenliğin muhafazasıdır. Bunun için gizlilik içeren silah ve yazılım teknolojilerinin yerli savunma sanayi sektörleri ile üretilmesi bu gerekliliğin yerine getirilmesi açısından atılacak ilk adımdır. İkinci gereklilik ise ekonomik açıdan olup yüksek maliyetli silah, teçhizat ve sistemlerin silahlı kuvvetler envanterine girebilmesi için kaynakların yurtdışına aktarılmaması hususudur. Ayrıca savunma sanayii sektöründe gösterilen faaliyetlerin yoğunluğu diğer sanayi sektörlerini de tetikleyerek teknoloji ve üretim kabiliyetlerini artırmasi ile sonuçlanabilecektir. Savunma sanayiine yatırım, başlangıçta maliyeti yüksek gibi görünse de uzun vadede istihdamı ve silah ihracatı yoluyla iktisadi büyümeye, ödemeler dengesine ve sanayileşmeye olumlu yönde katkı sağlamaktadır. 


\section{Summary}

\section{1}

There are a vast number of studies focused on the impact of defence spending on the economies of countries and the direction of this impact, if any. The effects of arms imports, which is the major defence spending item, on the macroeconomic performances of developing countries is a long-debated issue. Therefore, this study aims to determine the impact of the arms imports on economic growth, which lead to large deficits in the balance of payments of Turkey as a developing country. Among the defence spending items, the arms imports have the greatest impact potential on the economies of countries. Thus, the fundamental distinguishing feature of this study from many other similar studies is the inclusion of the arms import variable in the model, instead of the defence spending variable. The model covers the period starting from the establishment of the Undersecretariat for Defence Industries under the Ministry of National Defence in 1989, which has been established to ensure the production of weapons, weapon systems and military equipment for the Turkish Armed Forces using national facilities in particular. For this purpose, first of all, studies investigating the impact of arms imports and defence spending on economic growth were discussed in the theoretical framework and literature review sections of the study. Then, Bounds Testing based on the structural break Autoregressive Distributed-Lag Model (ARDL) was performed to determine the impact of the arms import on economic growth, using the 1990-2017 period data of Turkey. According to the test results of the study, no statistically significant correlation was found between the arms imports in Turkey and economic growth in the short run, but it was found that the arms imports have a negative impact on the economic growth in the long run. In the conclusion section of the study, some of the economic and political implications for Turkey were discussed based on the test results.
Güvenlik Stratejileri

Cilt: 16

Say1: 35 


\section{2}

Güvenlik Stratejileri

Cilt: 16

Sayı: 35

\section{KAYNAKÇA}

\section{Kitaplar}

ÖZMUCUR, Süleyman, The Economics of Defense and The Peace Dividend in Turkey, Boğaziçi Üniversitesi Basımevi, İstanbul, 1995.

ŞİMŞEK, Muammer, Üçüncü Dünya Ülkelerinde ve Türkiye'de Savunma Sanayii, SAGEB Yayınları, Ankara, 1989.

\section{Makaleler}

ALNIAK, Oktay, "Türk Savunma Sanayi Hakkında Genel Değerlendirme”, Savunma Sanayiindeki Teknolojik Gelişmeler Sempozyumu, 5-6 Haziran 1997, Kara Harp Okulu, Ankara.

ATEŞOĞLU, H. Sönmez, "Defense Spending and Aggregate Output in The United States", Defence and Peace, 2009, Cilt: 20(1), 21-26.

BAŞAR, Selim ve KÜNÜ, Serkan, "Savunma Harcamalarının İktisadi Büyümeye Etkisi”, Sosyal Bilimler Enstitüsü Dergisi, 2012, Cilt: 10, 1-30.

BENOIT, Emile, "Growth and Defense in Developing Countries", Economic Development and Cultural Change, 1978, Cilt: 26(2), 271-280.

BISWAS, Basudeb ve RAM, Rati, "Military Expenditures and Economic Growth in Less Developed Countries: An Augmented Model and Further Evidence", Economic Development and Cultural Change, 1986, Cilt: 34(2), 361-372.

BRZOSKA, Michael, "World Military Expenditures", Keith Hartley ve Todd Sandler, (ed.), Handbook of Defense Economics, Elsevier, Amsterdam, 1995, 45-67.

CHOWDHURY, Abdur R., "A Casual Analysis of Defense Spending and Economic Growth", The Journal of Conflict Resolution, 1991, Cilt: 35(1), 80-97.

DEGER, Saadet, "Economic Development and Defense Expenditure", Economic Development and Cultural Change, 1986, Cilt: 35(1), 179-196.

DAKURAH, Angson Henry, DAVIES, Stephen P. ve SAMPATH, Rajan K, "Defense Spending and Economic Growth in Developing Countries: A Causality Analysis", Journal of Policy Modeling, 2001, Cilt: 23(6), 651-658.

DEGER, Saadet ve SMITH, Ron, "Military Expenditure and Growth in Less Developed Countries", Journal of Conflict Resolution, 1983, Cilt: 27(2), 335-353.

DRITSAKIS, Nikolaos, "Defense Spending and Economic Growth: An Empirical Investigation for Greece and Turkey", Journal of Policy Modeling, 2004, Cilt: 26(2), 249-264.

DUNNE, Paul ve TIAN, Nan, "Military Expenditure, Economic Growth and Heterogeneity", Defence and Peace Economics, 2013, Cilt: 26(1), 15-31.

DUNNE, Paul ve VOUGAS, Dimitrios, "Military Spending and Economic Growth in South Africa: A Causal Analysis", Journal of Conflict Resolution, 1999, Cilt: 43(4), 521-537.

DUNNE, Paul, NIKOLAIDOU, Eftychia ve VOUGAS, Dimitrios, "Defence Spending and Economic Growth: A Causal Analysis for Greece and Turkey", Defence and Peace Economics, 2001, Cilt: 12(1), 5-26.

DUYAR, Metin ve KOÇOĞLU, Mustafa, "Askerî Harcamaların Ekonomik Büyüme Üzerine Etkisi; Sahra Altı Afrika Örneği”, Uluslararası Sosyal Araştırmalar Dergisi, 
Türkiye'de Silah İthalatının İktisadi Büyüme Üzerine Etkisi

2014, Cilt: 7(33), 703-722.

FREDERIKSEN, Peter C. ve LOONEY, Robert E., "Defense Expenditures and Economic Growth in Developing Countries", Armed Forces \& Society, 1983, Cilt: 9(4), 633-645.

GÖRKEM, Hilal ve IŞIK, Serkan, "Türkiye'de Savunma Harcamaları ve Ekonomik Büyüme Arasındaki İlişki (1968-2006)", Marmara Üniversitesi İktisadi ve İdari Bilimler Fakültesi Dergisi, 2008, Cilt: 25(2), 405-424.

GYIMAH-BREMPONG, Kwabena, "Defense Spending and Economic Growth in Subsaharan Africa: An Econometric Investigation", Journal of Peace Research, 1989, Cilt: 26(1), 79-90.

HEO, Uk, "The Relationship between Defense Spending and Economic Growth in The United States", Political Research Quarterly, 2010, Cilt: 63(4), 760-770.

JOERDING, Wayne H., "Economic Growth and Defense Spending: Granger Causality. Journal of Development Economics, 1986, Cilt: 21(1), 35-40.

KALYONCU, Hüseyin ve YÜCEL, Fatih, "An Analytical Approach on Defense Expenditure and Economic Growth: The Case of Turkey and Greece", Journal of Economic Studies, 2006, Cilt: 33(5), 336-343.

KARAGIANNI, Stella ve PEMPETZOGLOU, Maria, "Defense Spending and Economic Growth in Turkey: A Linear and Non-Linear Granger Causality Approach", Defence and Peace Economics, 2009, Cilt: 20(2), 139-148.

KARAGÖL, Erdal ve PALAZ, Serap, "Does Defense Expenditure Deter Economic Growth in Turkey? A Cointegration Analysis", Defence and Peace Economics, 2004, Cilt: 15(3), 289-298.

KAYA, Semanur Soyyiğit, "Türkiye'de Savunma Harcamalarının İktisadi Etkileri Üzerine Nedensellik Analizi (1970-2010)", Trakya University Journal of Social Science, 2013, Cilt: 15(2), 17-38.

KOLLIAS, Christos ve MAKRYDAKIS, Stelios, "A Note on the Causal Relationship between Defence Spending and Growth in Greece: 1955-93", Defence and Peace Economics, 2000, Cilt: 11(1), 173-184.

KOLLIAS, Christos, "Defence Spending and Growth in Turkey 1954-1993: A Causal Analysis", Defence and Peace Economics, 1997, Cilt: 8(2), 189-204.

KOLLIAS, Christos, MANOLAS, George ve PALEOLOGOU, Suzanna-Maria, "Defence Expenditure and Economic Growth in the European Union a Causality Analysis", Journal of Policy Modeling, 2004, Cilt: 26(5), 553-569.

KORKMAZ, Özge ve BİLGIN, Tuba, "Askerî Harcamalar ile Ekonomik Büyüme Arasındaki İlişki: Türkiye ve Amerika Birleşik Devletleri'nin Karşılaştırmalı Analizi”, International Journal of Economic \& Administrative Studies, 2017, Cilt: 18, 289-316.

KORKMAZ, Suna, "The Effect of Military Spending on Economic Growth and Unemployment in Mediterranean Countries", International Journal of Economics and Financial Issues, 2015, Cilt: 5(1), 273-280.

LACIVITA, Charles J. ve FREDERIKSEN, Peter C., "Defense Spending and Economic Growth an Alternative Approach to the Causality Issue", Journal of 


\section{Şerif CANBAY - Derya MERCAN}

734

Güvenlik Stratejileri

Cilt: 16

Sayı: 35

Development Economics, 1991, Cilt: 35(1), 117-126.

MINTZ, Alex ve STEVENSON, Randolph T., "Defense Expenditures, Economic Growth and the Peace Dividend: A Longitudinal Analysis of 103 Countries", Journal of Conflict Resolution, 1995, Cilt: 39(2), 283-305.

NA, Hou ve BO, Chen, "Cooperation for a Peaceful and Sustainable World Part 2: Military Expenditure and Economic Growth in South Asia", Contributions to Conflict Management, Peace Economics and Development, 2013, Cilt: 20, 213-223.

PAYNE, James E. ve ROSS, Kevin L., "Defense Spending and the Macroeconomy", Defence Economics, 1992, Cilt: 3(2), 161-168.

PESARAN, M. H., SHIN, Yongcheol ve SMITH, Richard J., "Bounds Testing Approaches to the Analysis of Level Relationships", Journal of Applied Econometrics, 2001, Cilt: 16(3), 289-326.

SEZGIN, Selami, "An Empirical Analysis of Turkey's Defence-Growth Relationships with a Multi-Equation Model (1956-1994)", Defence and Peace Economics, 2001, Cilt: 12(1), 69-86.

SEZGIN, Selami, "Country Survey X: Defence spending in Turkey", Defence and Peace Economics, 1997, Cilt: 8(4), 381-409.

TOPAL, Mehmet Hanefi, "Türkiye'de Askerî Harcamalar ile Ekonomik Büyüme Arasındaki İlişkinin Bir Analizi (1960-2016)”, Maliye Dergisi, 2018, Cilt: 174, 175202.

TUNCAY, Özhan, "Finansal Serbestleșme Sonrası Dönem Savunma Harcamalarının Ekonomik Analizi", Uluslararası Ekonomik Araștırmalar Dergisi, 2017, Cilt: 3(1), 23-37.

YAKOVLEV, Pavel, "Arms Trade, Military Spending, and Economic Growth", Defence and Peace Economics, 2007, Cilt: 18(4), 317-338.

YANTUR, Pelin ve GÜRSON, Ali Poyraz, "Savunma Harcamaları ve Ekonomik Büyüme Üzerine Araştırma: $\mathrm{ABD}$, Japonya ve Fransa Örneği”, İnsan ve Toplum Bilimleri Araştırmaları Dergisi, 2019, Cilt: 8(1), 163-182.

YILANCI, Veli ve ÖZCAN, Burcu, "Yapısal Kırılmalar Altında Türkiye için Savunma Harcamaları ile GSMH Arasındaki İlişkinin Analizi”, Cumhuriyet Üniversitesi İktisadi ve İdari Bilimler Dergisi, 2010, Cilt: 11(1), 21-33.

YILDIRIM, Jülide ve ÖCAL, Nadir, "Arms Race and Economic Growth: The Case of India and Pakistan", Defence and Peace Economics, 2006, Cilt: 17(1), 37-45.

YILDIRIM, Jülide, SEZGIN, Selami ve ÖCAL, Nadir, "Military Expenditure and Economic Growth in Middle Eastern Countries: A Dynamic Panel Data Analysis", Defence and Peace Economics, 2005, Cilt: 16(4), 283-295.

İnternet Kaynakları:

SIPRI Resmi İnternet Sayfas1, http://armstrade.sipri.org/armstrade/page/values.php (Erişim Tarihi: 14.04.2019).

The World Bank Resmî İnternet Sayfas1, https://data.worldbank.org/indicator/ NY.GDP.MKTP.CD (Erişim Tarihi: 14.04.2019). 